В. І. Федорченко, О. В. Ганчо, Н. О. Боброва, Т. С. Кириченко, Г. А. Лобань Вищий державний навчальний заклад України “Украӥнська медична стоматологічна академія”, м. Полтава

\title{
НАВЧАЛЬНО-МЕТОДИЧНЕ ТА ОРГАНІЗАЦІЙНЕ ЗАБЕЗПЕЧЕННЯ ОСВІТНЬОГО ПРОЦЕСУ ДЛЯ АНГЛОМОВНИХ СТУДЕНТІВ НА КАФЕДРІ МІКРОБІОЛОГІЇ, ВІРУСОЛОГІЇ ТА ІМУНОЛОГІЇ ВДНЗУ “УКРАЇНСЬКА МЕДИЧНА СТОМАТОЛОГІЧНА АКАДЕМІЯ”
}

\author{
V. I. Fedorchenko, O. V. Hancho, N. O. Bobrova, T. S. Kyrychenko, G. A. Loban \\ Ukrainian Medical Stomatological Academy, Poltava \\ EDUCATIONAL, METHODOLOGICAL AND ORGANIZATIONAL \\ TEACHING PROCESS PROVIDING FOR ENGLISH-SPEAKING \\ STUDENTS AT THE DEPARTMENT OF MICROBIOLOGY, VIRUSOLOGY \\ AND IMMUNOLOGY OF UKRAINIAN MEDICAL STOMATOLOGICAL \\ ACADEMY
}

\begin{abstract}
Мета роботи - аналіз стану методичного забезпечення навчального процесу з англомовними студентами на кафедрі мікробіології, вірусології та імунології ВДНЗУ “УМСА” для визначення у майбутньому доцільних дій у цьому напрямку діяльності викладацького колективу кафедри.

Основна частина. 3 метою подальшого покращення рівня знань з предмета на кафедрі мікробіології, вірусології та імунології постійно проводиться методична робота щодо створення, удосконалення та осучаснення методичних розробок для студентів з англійською мовою викладання. Методичні розробки кафедри направлені на сприяння студентам в отриманні інформації 3 предмета, успішне оволодіння практичними навичками та підготовку до складання незалежного тестування “Крок-1”. Також розробляються бази тестів для поточного контролю знань студентів.

Висновок. Навчально-методичне забезпечення освітнього процесу для англомовних студентів на кафедрі мікробіології, вірусології та імунології розробляється та вдосконалюється у напрямках інформаційного забезпечення, організації процесу оволодіння практичними навичками та контролю знань студентів.

Ключові слова: мікробіологія; вірусологія та імунологія; методичне забезпечення; англомовні студенти.

The aim of the work - to analyze the status of methodical provision of the educational process with English-speaking students at the Department of Microbiology, Virology and Immunology of UMSA to determine in the future the following appropriate actions in this direction of the teaching staff of the department.

The main body. In order to further improving the level of knowledge on the subject at the Department of Microbiology, Virology and Immunology systematic work is being done on the creation, refinement and modernization of methodological developments for students with English language teaching. The methodological developments of the department are aimed at facilitating students in obtaining information on the subject, successfully mastering practical skills and preparing for the independent testing of Krok-1. Also test bases for current student knowledge control are developed.

Conclusion. Educational and methodological support of the educational process for English-speaking students at the Department of Microbiology, Virology and Immunology is being developed and improved in the areas of information support, organization of the process of mastering practical skills and controlling knowledge of students.
\end{abstract}

Key words: microbiology; virology and immunology; methodical support; English-speaking students.

Вступ. Можливість якісної підготовки спеціалістів, зокрема і медичного профілю, залежить від багатьох чинників. Одними з найбільш значущих 3 них $є$ професіоналізм викладача та забезпеченість

(C) В. І. Федорченко, О. В. Ганчо, Н. О. Боброва та ін. навчального процесу методичними матеріалами [1]. Беззаперечним є взаємозв’язок між цими складовими. Чим більш професійними є дії викладацького складу, тим якісніший методичний продукт вони можуть розробляти. Водночас якісні методичні 
матеріали можуть посприяти пришвидшенню професійного зростання молодих викладацьких кадрів, а також забезпеченню більш сталого рівня якості навчання студентів.

Тому питанню методичного забезпечення постійно приділяється значна увага на чисельних методичних конференціях протягом багатьох років [1]. Поява напрямку навчання 3 англійською мовою викладання предмета додала до розробки методичних матеріалів нових задач, часто з певними специфічними особливостями, пов'язаними 3 рівнем володіння мовою навчання для студентів та мовою викладання для викладачів. За останнє десятиріччя на кафедрах ВДНЗУ “УМСА” значною мірою сформувались групи викладачів, що володіють англійською мовою на достатньому рівні. Зростанню рівня володіння мовою сприяли відповідний базовий рівень знань викладачів, залучених до викладання в англомовних групах, їх самоосвіта. Курси англійської мови, які регулярно організовуються для викладацького складу у ВДНЗУ “УМСА”, також відіграють важливу роль у цьому питанні.

Методичне забезпечення для англомовних студентів має відповідати ряду об’єктивних додаткових вимог порівняно з тим, що стосується інших категорій студентів. Це пов'язано, зокрема, 3 різним рівнем володіння англійською мовою самими студентами. Лише деякі з них відносяться до категорії носіїв мови. Інші можуть потребувати мовної підтримки для успішного засвоєння матеріалу з предмета, швидкість сприйняття ними інформації може бути помітно нижчою, ніж в інших. У першу чергу, це стосується студентів молодших курсів. У той же час англомовні студенти можуть використовувати різні джерела інформації з предмета: методичні розробки, посібники на паперових носіях, які видавалися в різних країнах, та навіть інтернет-ресурси. Різні 3 цих джерел можуть містити дещо різний обсяг інформації та дещо модифікований зміст теми. На прикладі мікробіології таку різницю змісту можна проілюструвати зокрема різними назвами живильних середовищ, які застосовуються для культивування бактерій певних груп.

Отже, методичні посібники, що розробляються для англомовних студентів, мають бути зорієнтованими на те, щоб допомогти студентам з різним рівнем мовної підготовки та з різними джерелами отримання інформації з предмета звести кінцевий результат навчання до певного спільного знаменника. Наслідком успішного вивчення студентом даного предмета має бути успішне складання модулів, семестрової підсумкової атестації СПА, незалежного тестування “Крок-1”.

Мета роботи - аналіз стану методичного забезпечення навчального процесу з англомовними студентами на кафедрі мікробіології, вірусології та імунології ВДНЗУ “УМСА” для визначення у майбутньому наступних доцільних дій у цьому напрямку діяльності викладацького колективу кафедри.

Основна частина. Для того щоб методичні матеріали з предмета для англомовних студентів ефективно сприяли зазначеним вище задачам, на кафедрі мікробіології, вірусології та імунології ВДНЗУ “УМСА” постійно проводиться робота щодо удосконалення методичних розробок, що були створені раніше, а також створення нових за певними визначеними напрямками. Усі ці методичні розробки можна умовно поділити на декілька категорій.

У першу категорію можуть бути включені методичні розробки-інструкції. Саме такими є методичні рекомендації для студентів до практичного заняття. Вони розроблені та за потреби вдосконалюються за загальноприйнятою схемою, структурою, та відповідно до актуальної програми з предмета (за профілем “Медицина” або “Стоматологія” відповідно) [2, 3]. Дані методичні розробки створюються відповідно до аналогічних україномовних варіантів до кожної теми.

Друга категорія - інформаційні джерела. Розробка таких методичних розробок спрямована на подання найголовніших питань 3 теми у стислій формі. На противагу основним загальноприйнятим посібникам на паперових та електронних носіях, такі методичні розробки можуть стати у пригоді студентам, які зазнають певних мовних труднощів. Такі навчальні матеріали внормовують час, потрібний для ознайомлення таких студентів з матеріалами теми до того моменту, коли вони досягнуть достатнього рівня знання мови. Такі інформаційні джерела можуть бути використані студентами також для швидкого повторення матеріалів теми. Даний напрямок роботи є надзвичайно актуальним 3 огляду на відсутність загальнонаціональних посібників з предмета, виданих англійською мовою.

Третя категорія методичних розробок кафедри альбоми для практичних занять. В альбомах студенти мають частину інформації, представленої у методичних вказівках до практичних занять. Це, зокрема, перелік теоретичних питань до практичного заняття, перелік питань для самостійного вивчення, перелік практичних навичок, якими слід оволодіти. 
Важливою складовою частиною даної методичної розробки є перелік практичних завдань, які мають бути виконані на практичному занятті, з відповідним супроводом у вигляді заготовлених полів зору, де студентами буде зображено мікроорганізми з їх характерними морфологічними та тинкторіальними властивостями; таблиці для обліку серологічних реакцій, місця для запису висновків до завдання; таблиці для внесення інформації щодо специфічних імунобіологічних препаратів, що можуть бути використані для специфічної профілактики та лікування відповідної інфекції, тощо. 3 даним методичним посібником студенти працюють на занятті, заповнюють відповідні форми належною інформацією. Ця розробка робить більш ефективним всебічне обговорення виконуваних завдань, висновків до них. Студент зобов’ язаний оформлювати даний протокол на занятті і давати його на підпис до завершення заняття. Таким чином, дана методична розробка оптимізує роботу студента, направлену на засвоєння теоретичних питань та оволодіння практичними навичками.

Остання, четверта категорія методичних матеріалів - це тестові завдання різного рівня складності. Розроблено тести у вигляді роздаткового матеріалу, які можуть бути використані на кожному занятті для поточного контролю знань студентів.

\section{Список літератури}

1. Досвід викладання англомовним студентам мікробіології, вірусології та імунології на сучасному етапі розвитку медичної освіти в Україні / Г. А. Лобань, I. В. Комишан, О. В. Ганчо [та ін.] // Основні напрямки удосконалення підготовки медичних кадрів у сучасних умовах : матеріали Всеукр. навч.-наук. конф. 3 міжнар. участю. - Полтава, 2015. - С. 147-149.

2. Мікробіологія, вірусологія та імунологія. Примірна програма навчальної дисципліни підготовки фахівців другого (магістерського) рівня вищої освіти кваліфікації
Окремі набори тестів до кожної теми створені для бази даних, що використовується для відпрацювання пропущених практичних занять із використанням комп’ютерних технологій.

Створена такожбаза даних на основі тестів “Крок-1” з предмета. Студенти працюють 3 даними тестами самостійно під час підготовки до практичного заняття. Потім дані матеріали розглядаються на занятті і знання тестів впливає на кінцеву оцінку студента. Знання даної бази тестів визначається також у ході поточних та підсумкового комп’ютерного тестування, що має на меті допомогти студентам успішно пройти етап незалежного тестування.

Слід відзначити, що зазначені методичні матеріали (за винятком бази тестів для поточного контролю рівня знань) доступні для студентів в електронному вигляді в електронній бібліотеці вищого навчального закладу. Студенти мають змогу самостійно роздрукувати усе, що потрібно їм для виконання своїх навчальних задач.

Висновок. Таким чином, навчально-методичне забезпечення освітнього процесу для англомовних студентів на кафедрі мікробіології, вірусології та імунології ВДНЗУ “Українська медична стоматологічна академія” розробляється та вдосконалюється в напрямках інформаційного забезпечення, організації процесу оволодіння практичними навичками та контролю знань студентів.

освітньої “Магістр медицини” кваліфікації професійної “Лікар” / [В. П. Широбоков, В. Г. Войцеховський, О. В. Салата та ін.]. - К., 2017. - 61 с.

3. Мікробіологія, вірусологія та імунологія. Примірна програма навчальної дисципліни підготовки фахівців другого (магістерського) рівня вищої освіти кваліфікації освітньої “Магістр стоматології” кваліфікації професійної “Лікар-стоматолог” / [В. П. Широбоков, В. Г. Войцеховський, О. В. Салата та ін.]. - К., 2017. 68 c.

\section{References}

1. Loban, G.A., Komishan, I.V., \& Hancho, O.V. (2015). Dosvid vykladannia anhlomovnym studentam mikrobiolohii, virusolohii ta imunolohii na suchasnomu etapi rozvytku medychnoi osvity v Ukraini [Teaching experience for English-speaking students of microbiology, virology and immunology at the present stage of medical education development in Ukraine]. Materialy Vseukrainskoi navchalno-naukovoi konferentsii z mizhnarodnoiu uchas- tiu "Osnovni napriamky udoskonalennia pidhotovky medychnykh kadriv u suchasnykh umovakh" - Materials of the All-Ukrainian Educational-Scientific Conference with International Participation "Basic Directions of Improvement of Training of Medical Personnel in Modern Conditions". (pp.147-149). Poltava [in Ukrainian].

2. Shyrobokov, V.P., Voitsekhovskyi, V.H., \& Salata, O.V. (2017). Mikrobiolohiia, virusolohiia ta imunolohiia. 
Prymirna prohrama navchalnoi dystsypliny pidhotovky fakhivtsiv druhoho (mahisterskoho) rivnia vyshchoi osvity kvalifikatsii osvitnoi "Mahistr medytsyny" kvalifikatsii profesiinoi “Likar” [Microbiology, Virology and Immunology. Probationary program of training of specialists of the second (master's) level of higher education qualification of educational "Master of Medicine"professional qualification "Doctor"]. Kyiv [in Ukrainian].

3. Shyrobokov, V.P., Voitsekhovskyi, V.H., \& Salata, O.V. (2017). Mikrobiolohiia, virusolohiia ta imunolohiia.
Prymirna prohrama navchalnoi dystsypliny pidhotovky fakhivtsiv druhoho (mahisterskoho) rivnia vyshchoi osvity kvalifikatsii osvitnoi "Mahistr stomatolohii" kvalifikatsii profesiinoi "Likar-stomatoloh" [Microbiology, Virology and Immunology. Ad hoc program of study discipline for the training of specialists of the second (master's) level of higher education qualification of the educational "Master of dentistry" professional qualification "Doctor-dentist”]. Kyiv [in Ukrainian].

Електронна адреса для листування: microbiolog@umsa.edu.ua

Отримано 11.04.18 